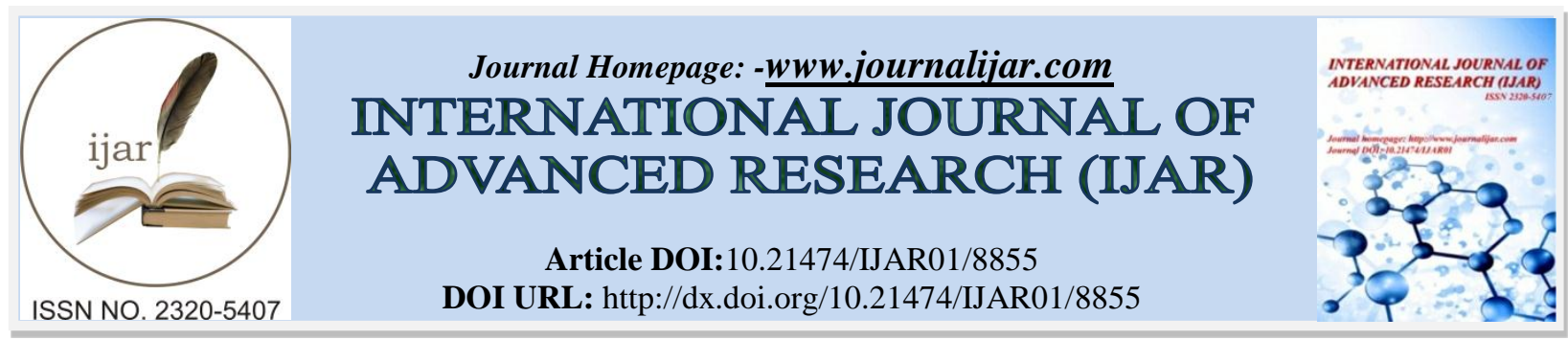

RESEARCH ARTICLE

\title{
A COMPARISON OF COBLATION VERSUS CONVENTIONAL TONSILLECTOMY IN A TERTIARY CARE CENTER.
}

Dr. Annamalai.v and Dr.Palaniappan.S Ms,Dlo.

\section{Manuscript Info}

Abstract

Manuscript History

Received: 10 February 2019

Final Accepted: 12 March 2019

Published: April 2019

\section{Introduction:-}

This is a prospective randomised study to compare the coblation and conventional tonsillectomy techniques in view of their advantages and complications in a tertiary care center. It was conducted and follow up was done for 6 months.

It compares, Blood loss Post op pain at 6 hrs and POD-1, Return to normal diet, Post op complications.

\section{Materials And Methods:-}

1. Design of study: Prospective randomised cohort study Number of patients studied : $n=50$

2. Collaborating departments: nil

3. Selection of subjects : 5 to 20 years

4. Study Centre : Department of ENT

This study compares the result of coblation with conventional tonsillectomy in aspects of

1. Blood loss

2. Pain post operatively at $6 \mathrm{hrs}$ and POD-1

3. Return to normal diet

4. Complications

5. 50 patients were divided in to 2 groups of equal numbers

6. In one group tonsillectomies were done by coblation method and in other group done by conventional method

7. The patients were randomly divided to either groups of equal numbers

8. All surgeries were done under general anaesthesia

9. All patients were kept for 3 days in the hospital

10. Intra operative blood loss was measured by weighing the gauze and cotton ball before and after the procedure and by measuring the amount in suction bottle deducted from saline

11. All patients were given pre operative antibiotics and post operative analgesics

12. Post operative pain score was charted at $6 \mathrm{hrs}$ post operatively and POD-1 using visual analog scale

13. Patients and parents were asked to make note of any complications

14. Patients were reviewed in clinic on $7^{\text {th }}$ POD 


\section{Inclusion criteria}

1. Indications for tonsillectomy in our study are chronic recurrent tonsillitis

2. Recurrent attacks of tonsillitis

3. 7 episodes in 1year

4. 5 episodes per year for 2 years

5. 3 episodes per year for 3 years

6. Age 5-20yrs. (with out any history of tonsillitis within 4 weeks prior to surgery).

\section{Exclusion criteria}

1. Age $<5$ yrs, $>20 y r s$

2. Acute infection

3. Anaemia $-\mathrm{hb}<10 \mathrm{gm} / \mathrm{dl}$

4. Bleeding diathesis

5. Coagulation disorders

6. Uncontrolled systemic diseases

\section{Symptoms for evaluation}

1. Throat discomfort

2. Odynophagia

3. Unpleasant taste

4. Foetor

5. Voice change

6. Failure to thrive

7. Fatigue

8. Loss of appetite

Fig 1:-Visual analog scale for pain

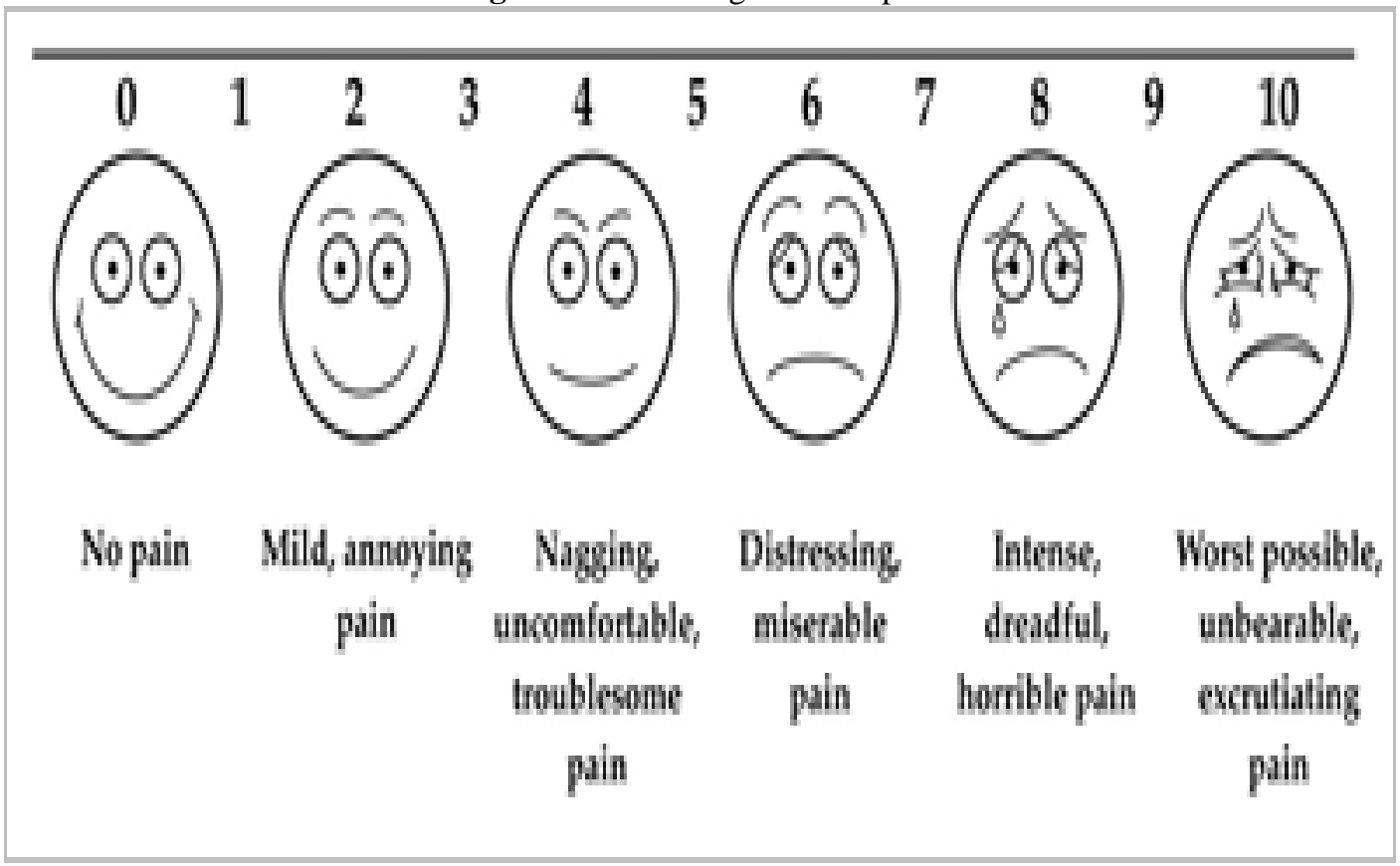

\section{Signs for Evaluation}

1. Hyperaemic anterior pillars

2. Enlarged JD nodes

3. Irwin moore sign- pus pouring out of tonsillarcryptswith application of pressure on anterior tonsillar pillars 
4. Enlarged or atrophic tonsils

Pre operative anesthetic assessment was done

All basic blood investigations including bleeding parameters were done.

Informed consent:

1. Informed consent was obtained from the patients and parents after explaining to them the procedure and objective of the study.

2. The consent form described the purpose of the study and the procedure to be followed.

\section{Conventional tonsillectomy procedure}

This is the most commonly used method to perform tonsillectomy today. In sister rose's position patient is placed, naso tracheal or oro tracheal intubation done, boyledavis mouth gag with appropriate tongue blade placed,throat pack kept,using walsellum tonsil holding forceps left tonsil is medially retracted, using forceps incision is made at the junction of anterior pillar and superior pole the mucosal overlying the tonsillar capsule is incised and plane of loose areolar tissue between the pharyngeal musculature and tonsil is dissected with tonsillar dissectors and gauze, and the tonsil is mobilized. The tonsil is dissected along with its capsule and lifted out of its bed till theinferior pole. It is removed using a tonsillar snare which is also known as the Eve's tonsillar snare.

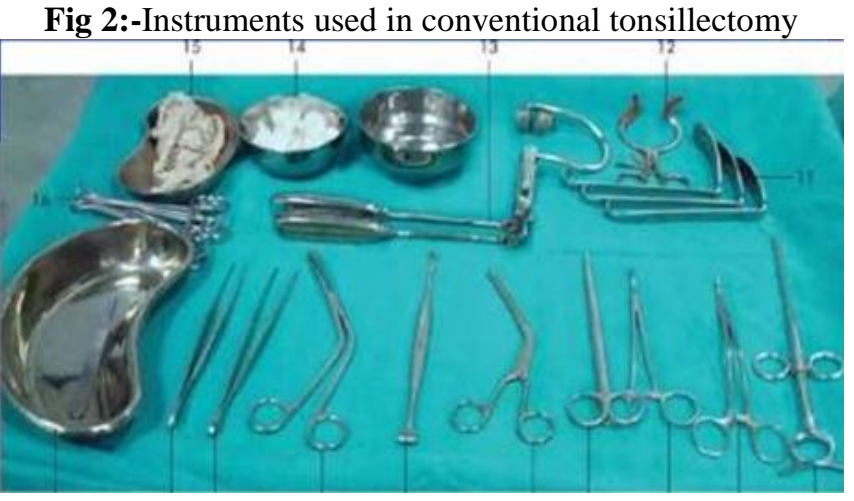

\section{Coblation tonsillectomy procedure}

In sister rose's position patient is placed,naso tracheal or oro tracheal intubation done, boyledavis mouth gag with appropriate tongue blade placed,throat pack kept,under microscope using walsellum tonsil holding forceps left tonsil is medially retracted ,using coblationtonsillar wand incision is made at the junction of anterior pillar and superior pole the mucosal overlying the tonsillar capsule is incised and plane of loose areolar tissue between the pharyngeal musculature and tonsil is dissected, and the tonsil is mobilized. The tonsil is dissected along with its capsule and lifted out of its bed till inferior pole. It is removed using tonsillarwand,bleeding points are coagulated using the wand.same procedure is done on the other side. 


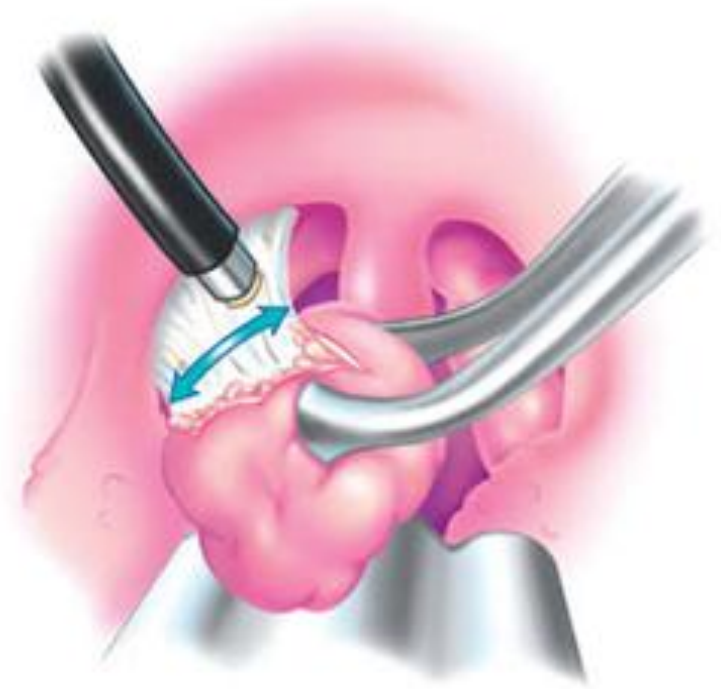

Fig 3:-Intra operative picture of coblation tonsillectomy.

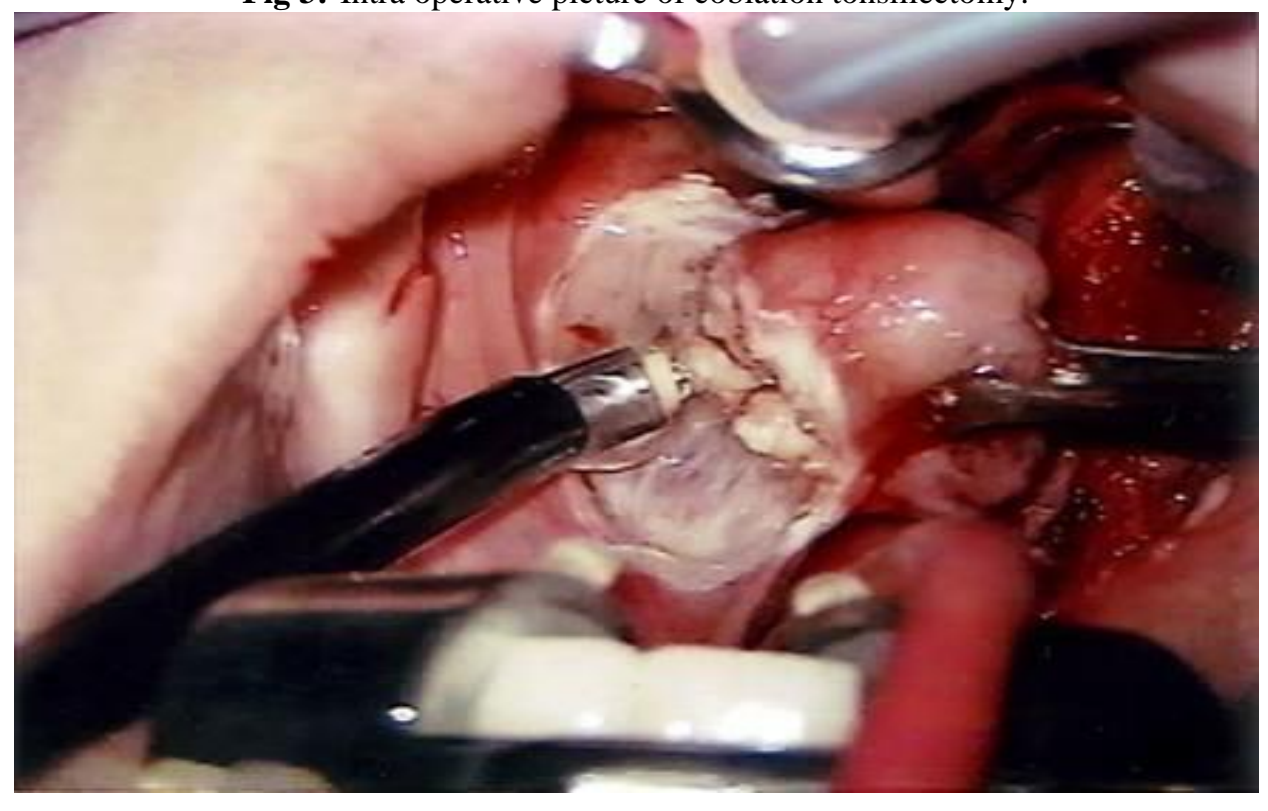

Fig 4:-Coblation wand with Machine 


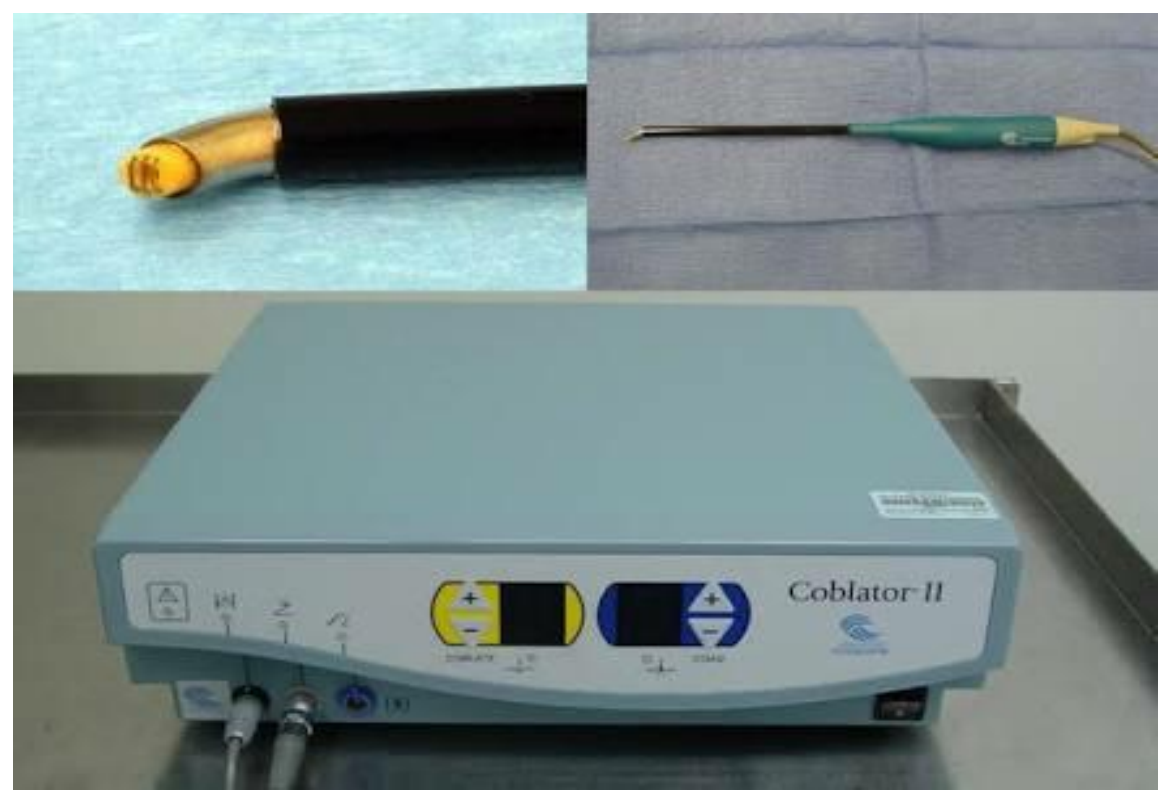

Table 1:-Results Of The Study Conducted

\begin{tabular}{|l|l|l|}
\hline Age & Coblation group & \% \\
\hline $5-10 y e a r s$ & 16 & 64 \\
\hline $11-15$ years & 5 & 20 \\
\hline $16-20$ years & 4 & 16 \\
\hline Total & $\mathbf{2 5}$ & $\mathbf{1 0 0}$ \\
\hline
\end{tabular}

Distribution of patients according to age in coblation

1. Most of the patients were between 5-10years

2. Mean -6.5 years

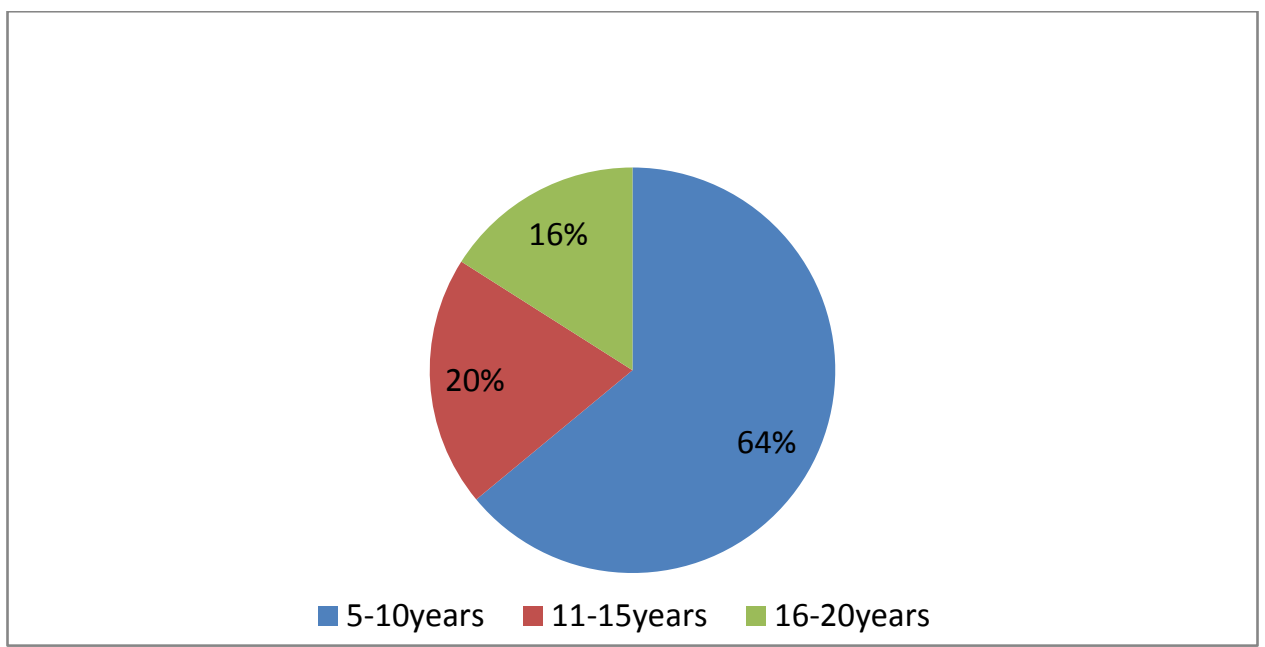

Pie Diagram 1:-Showing Distribution of Patients According to Age in Coblationtonsillectomy

Table 2:-Distribution of patients according to age in Conventional Group

\begin{tabular}{|l|l|l|}
\hline Age & Conventional group & $\%$ \\
\hline
\end{tabular}




\begin{tabular}{|l|l|l|}
\hline $5-10$ years & 18 & 72 \\
\hline $11-15$ years & 6 & 24 \\
\hline $16-20$ years & 1 & 4 \\
\hline Total & $\mathbf{2 5}$ & $\mathbf{1 0 0}$ \\
\hline
\end{tabular}

Most of the patients were between 5-10years

Mean - 6years

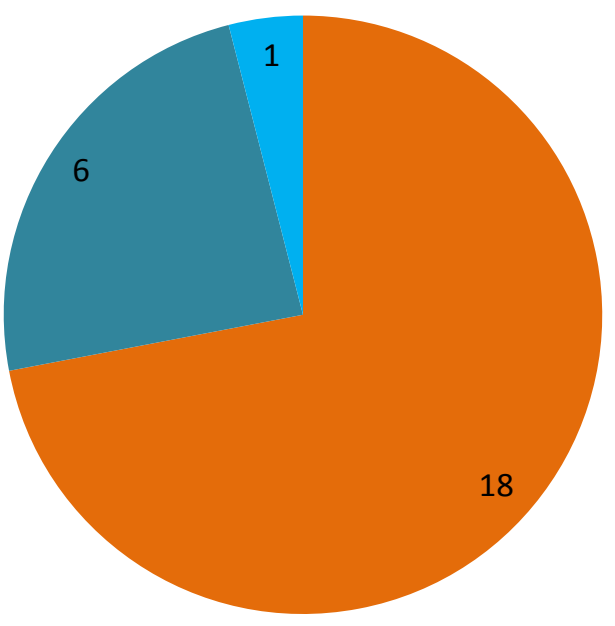

5-10years

-11-15years

16-20years

Pie Diagram 2:-Showing Distribution of Patients According to Age in Conventional tonsillectomy

Table 3:-Distribution of patients according to sex in coblation Group.

\begin{tabular}{|l|l|l|}
\hline Sex & Coblation group & $\%$ \\
\hline Male & 14 & 56 \\
\hline Female & 11 & 44 \\
\hline Total & $\mathbf{2 5}$ & $\mathbf{1 0 0}$ \\
\hline
\end{tabular}




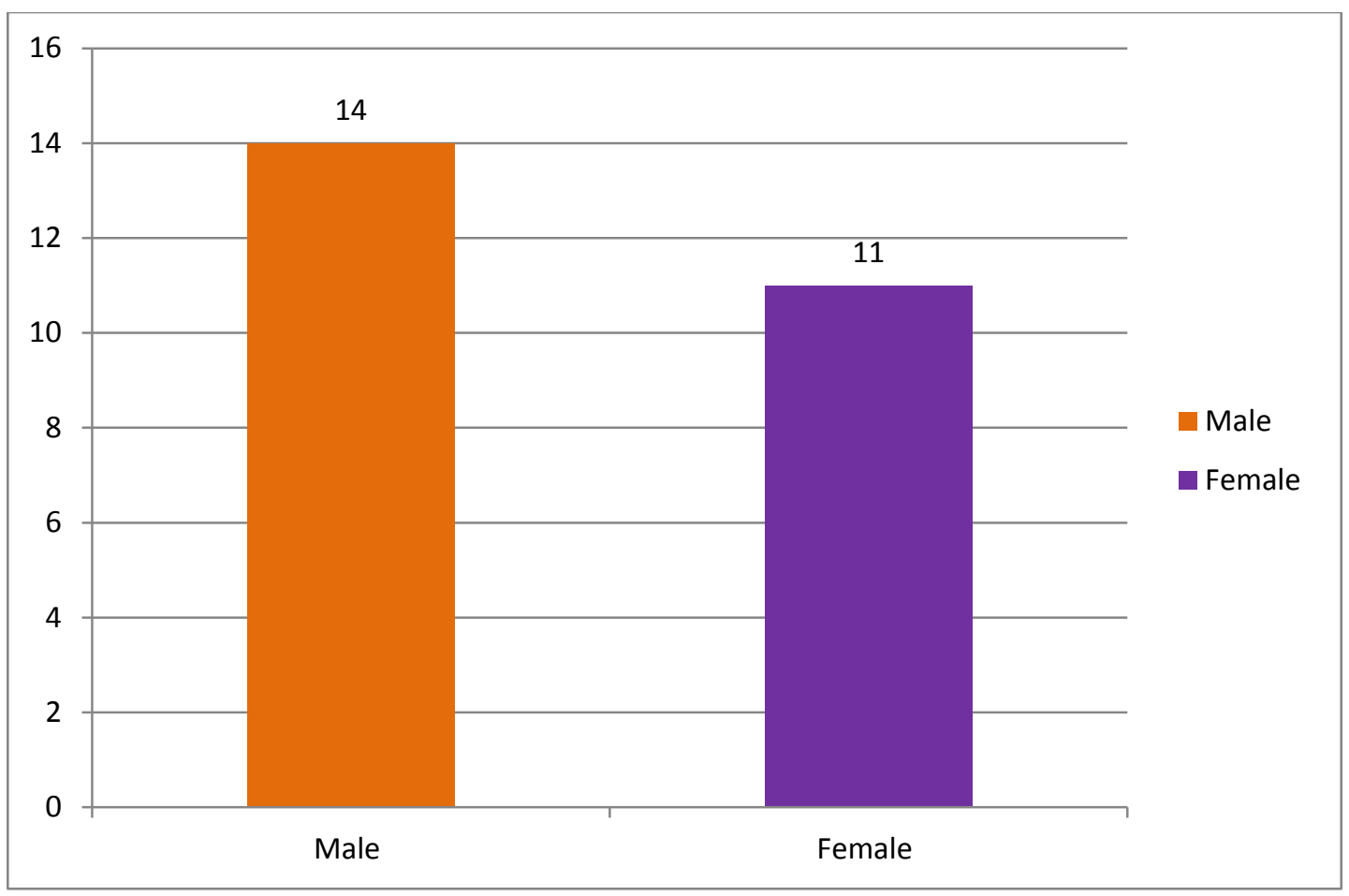

Bar Diagram 1:-Showing Distribution of Patients According to sex in coblation tonsillectomy

Table 4:-Distribution of patients according to sex in Conventional Group

\begin{tabular}{|l|l|l|}
\hline Sex & Conventional group & $\%$ \\
\hline Male & 13 & 52 \\
\hline Female & 12 & 48 \\
\hline Total & $\mathbf{2 5}$ & $\mathbf{1 0 0}$ \\
\hline
\end{tabular}

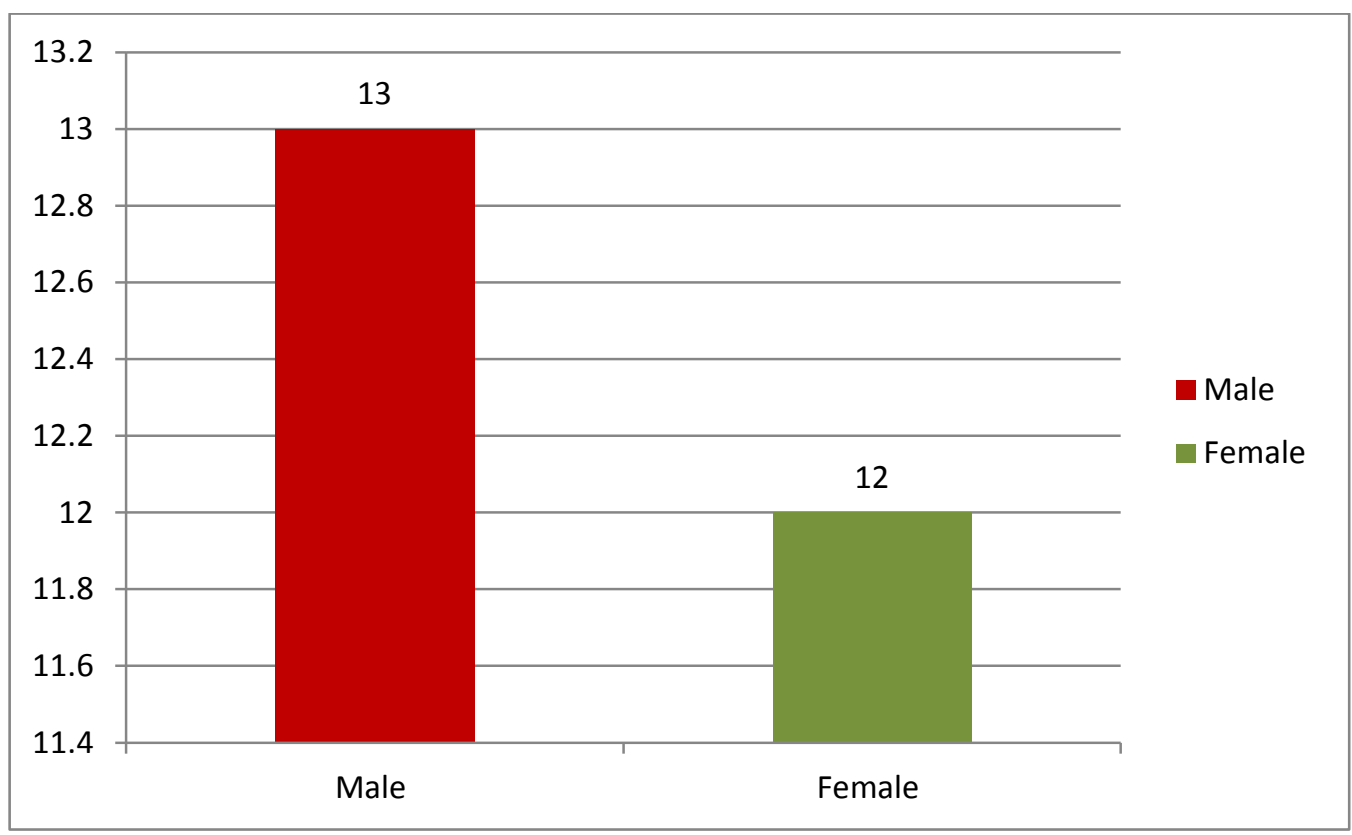

Bar Diagram 2:-Showing Distribution of Patients According to sex in Conventional tonsillectomy 
Table 5:-Distribution of symptoms incoblation method

\begin{tabular}{|l|l|l|}
\hline symptoms & coblation group & \% \\
\hline Odynophagia & 14 & 56 \\
\hline Throat discomfort & 5 & 20 \\
\hline Odynophagia and Throat discomfort & 2 & 8 \\
\hline Ear ache & 2 & 8 \\
\hline Throat discomfort and Ear ache & 2 & 8 \\
\hline
\end{tabular}

Most of the patients presented with odynophagia followed by throat discomfort .

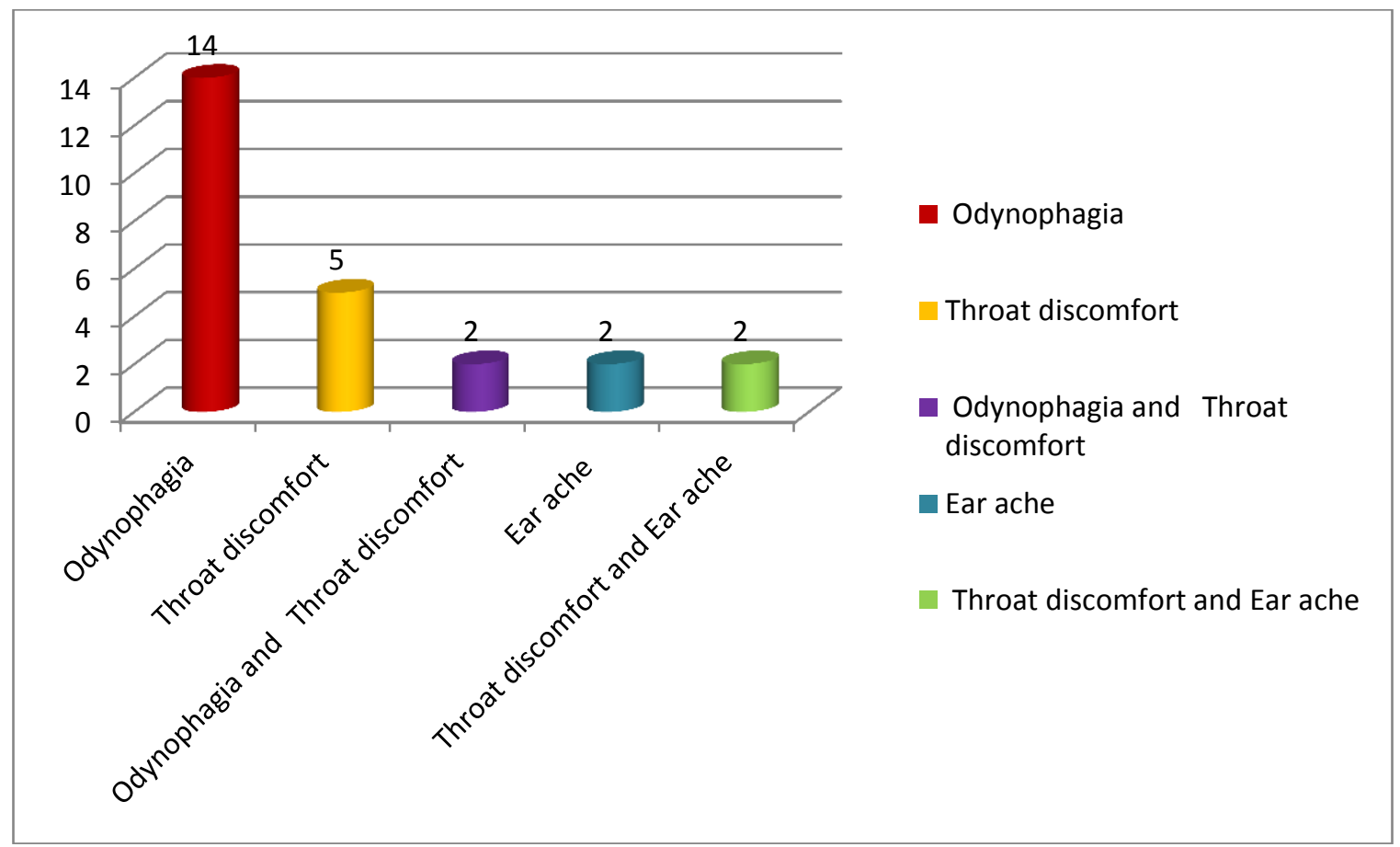

Bar Diagram 3:-Showing Distribution of Patients According to symptoms in coblation tonsillectomy

Table 6:-Distribution of symptoms in Conventional method

\begin{tabular}{|l|l|l|}
\hline symptoms & Conventional group & $\%$ \\
\hline Odynophagia & 10 & 40 \\
\hline Throat discomfort & 7 & 28 \\
\hline Odynophagia and Throat discomfort & 1 & 4 \\
\hline Ear ache & 4 & 16 \\
\hline Throat discomfort and Ear ache & 3 & 12 \\
\hline
\end{tabular}




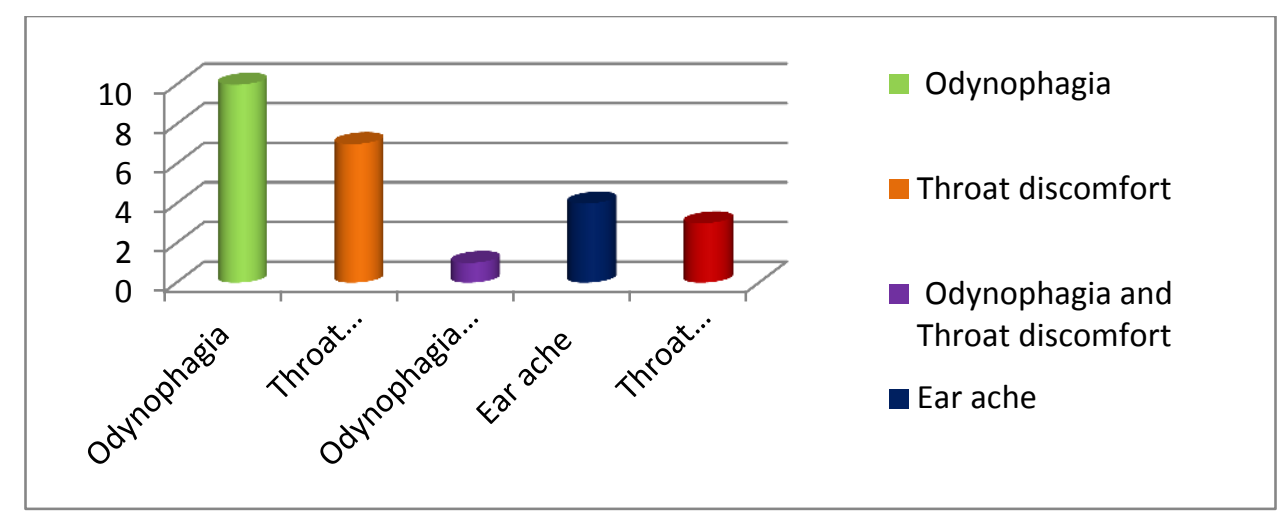

Bar Diagram 4:-Showing Distribution of Patients According to symptoms in Conventional tonsillectomy

Table 7:-Duration of symptoms in coblation method

\begin{tabular}{|l|l|l|}
\hline Duration & Coblation group & $\%$ \\
\hline 0 -6months & 7 & 28 \\
\hline 6months -1 year & 10 & 40 \\
\hline 1-3years & 8 & 32 \\
\hline
\end{tabular}

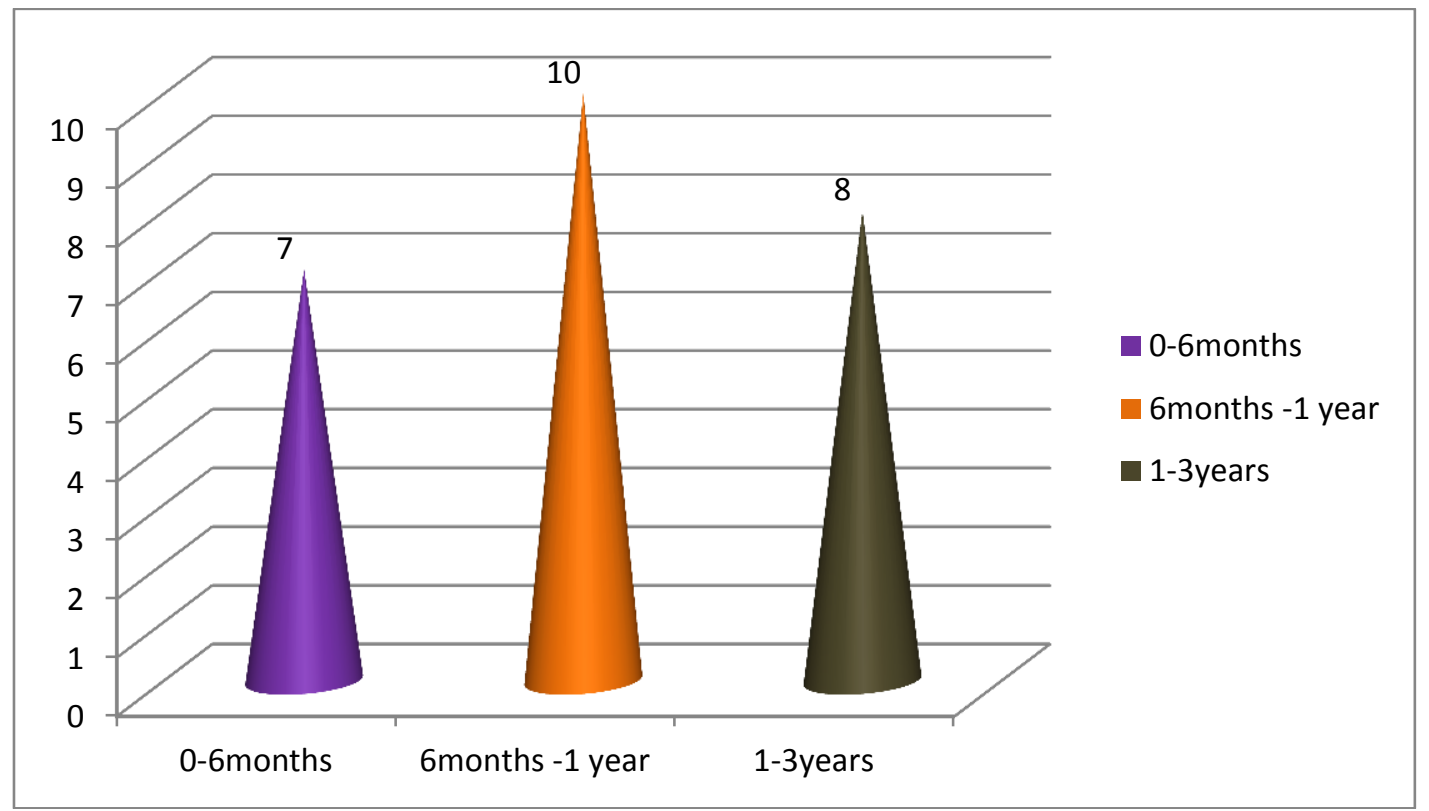

Diagram1:- Showing Duration of symptoms in coblation method

Table 8:-Duration of symptoms in Conventional method

\begin{tabular}{|l|l|l|}
\hline Duration & Conventional group & \% \\
\hline $0-6$ months & 5 & 20 \\
\hline 6months -1 year & 14 & 56 \\
\hline 1-3years & 6 & 24 \\
\hline
\end{tabular}




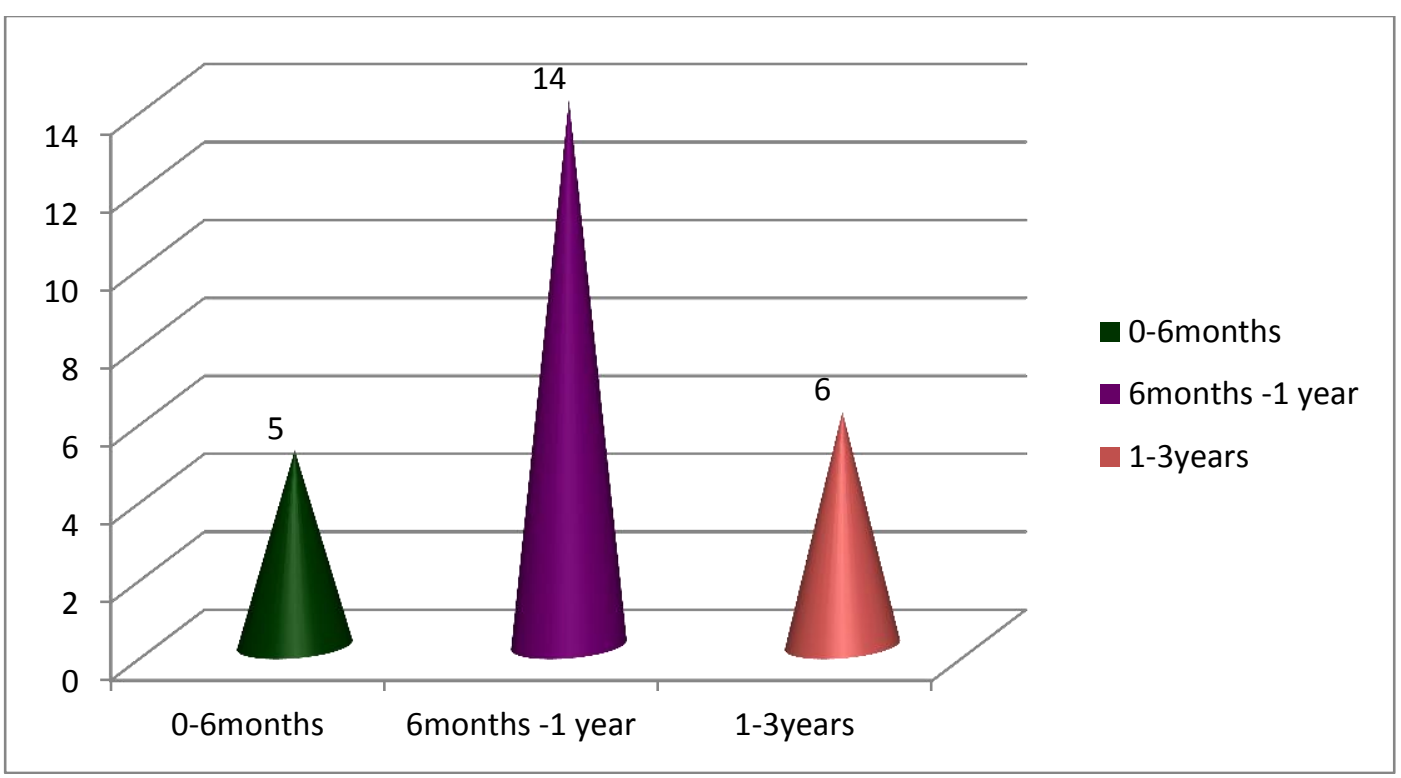

Diagram 2:-Showingsymptoms in Conventional method

Table 9:-Grading of tonsil in coblation group

\begin{tabular}{|l|l|l|}
\hline Grade & coblation group & $\%$ \\
\hline Grade I & 0 & 0 \\
\hline Grade II & 0 & 0 \\
& & \\
\hline Grade III & 22 & 88 \\
\hline Grade IV & 3 & 12 \\
\hline
\end{tabular}

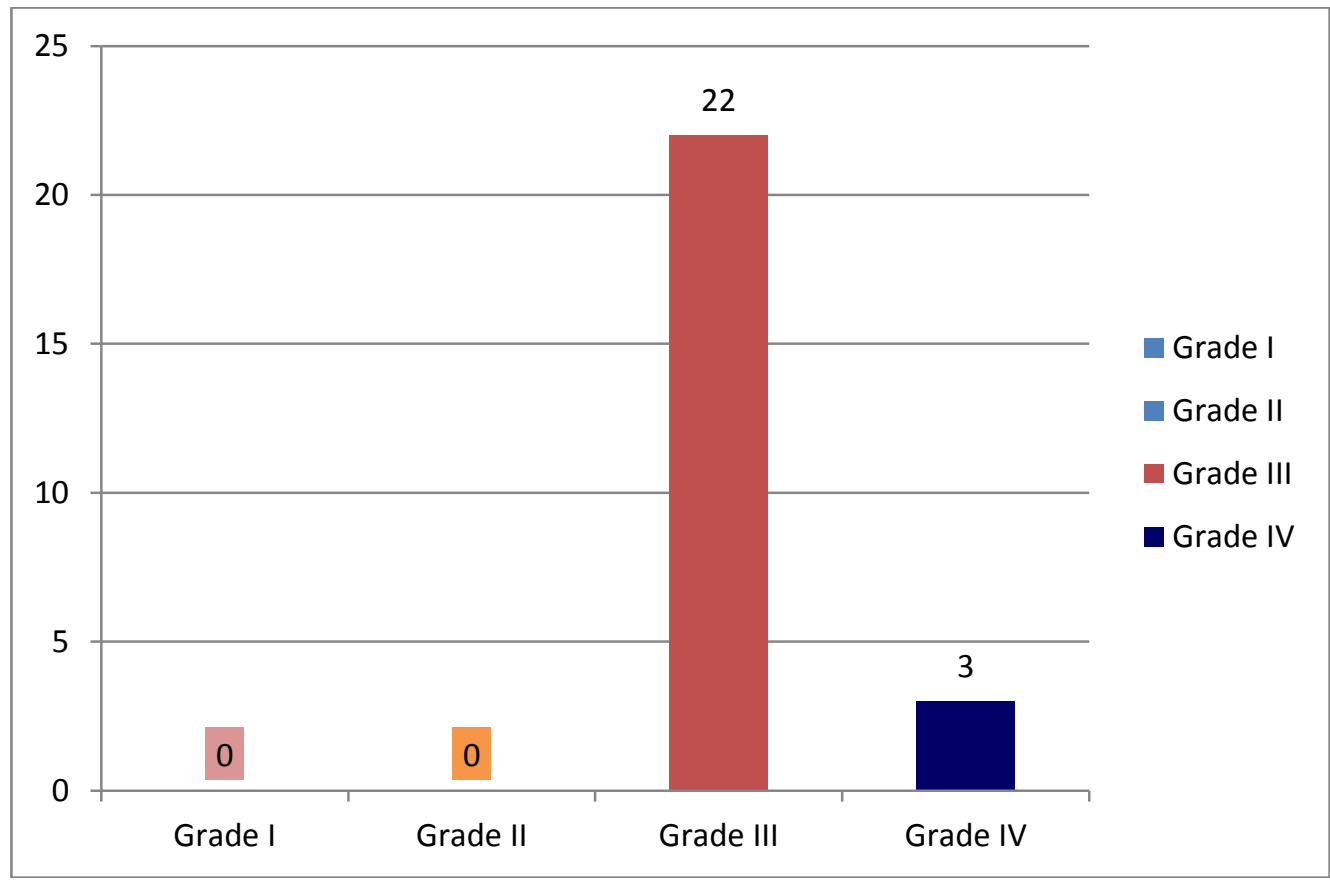

Bar diagram 5:-showing grading of tonsil in coblation group 
Table 10:-Grading of tonsil in Conventional group

\begin{tabular}{|l|l|l|}
\hline Grade & Conventional group & \% \\
\hline Grade I & 0 & 0 \\
\hline Grade II & 0 & 0 \\
& & \\
\hline Grade III & 22 & 88 \\
\hline Grade IV & 3 & 12 \\
\hline
\end{tabular}

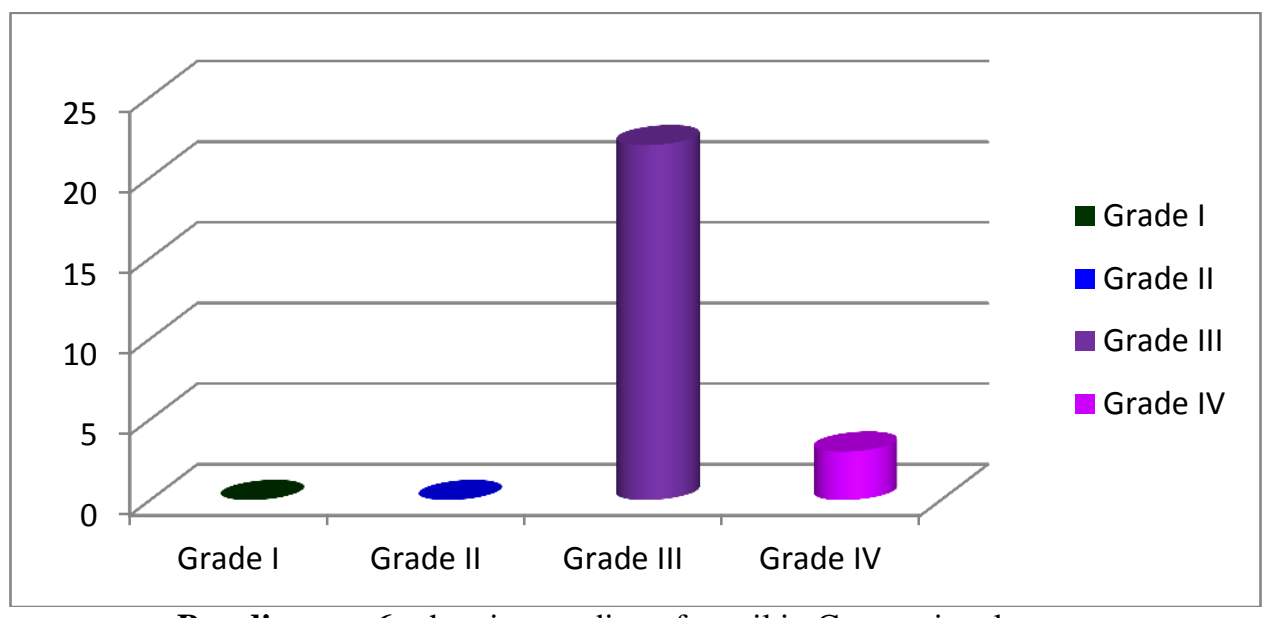

Bar diagram 6:-showing grading of tonsil in Conventional group

Table 11:-Intra operative blood loss in [ml] in coblation group

\begin{tabular}{|l|l|}
\hline Blood loss in $\mathbf{~ m l}$ & Coblation group \\
\hline Minimum loss & $20 \mathrm{ml}$ \\
\hline Maximum loss & $70 \mathrm{ml}$ \\
\hline
\end{tabular}

Mean blood loss $36 \mathrm{ml}$

Table 12:-Intra Operative Blood loss in [ml] in Conventional group

\begin{tabular}{|l|l|}
\hline Blood loss in $\mathbf{~ m l}$ & Conventional group \\
\hline Minimum loss & $55 \mathrm{ml}$ \\
\hline Maximum loss & $150 \mathrm{ml}$ \\
\hline
\end{tabular}

Mean blood loss $90.6 \mathrm{ml}$

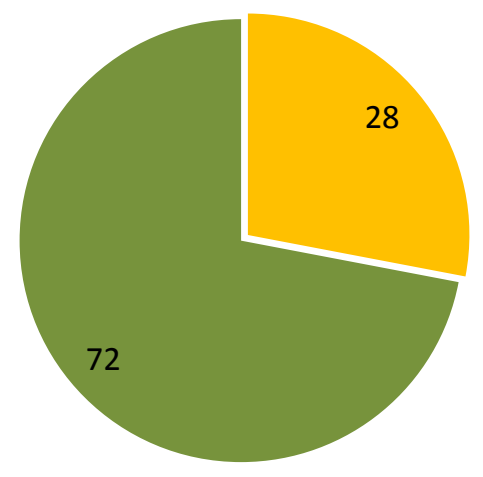

Mean blood loss $36 \mathrm{ml}$

Mean blood loss $90.6 \mathrm{ml}$ 
Table 13:-Comparison of Post-operative pain scorebetween coblation and conventional group after 6hrs

\begin{tabular}{|l|l|l|}
\hline 6hrs & coblation & Conventional \\
\hline Minimum score & 2 & 3 \\
\hline Maximum score & 3 & 6 \\
\hline
\end{tabular}

Table 14:-Comparison of Post-operative pain scorebetween coblation and conventional groupafter POD-1

\begin{tabular}{|l|l|l|}
\hline 6hrs & coblation & Conventional \\
\hline Minimum score & 1 & 1 \\
\hline Maximum score & 2 & 3 \\
\hline
\end{tabular}

1. In collation group at $6 \mathrm{hrs}$ Post operatively minimum score was 2 and maximum score was 3

2. On POD 1 minimum score was 1 and maximum score was 2

3. In Conventional group at $6 \mathrm{hrs}$ Post operatively minimum score was 3 and maximum score was 6

4. On POD 1 minimum score was 1 and maximum score was 3

Table 15:-Comparison of 'Return to normal diet' in coblation and conventional group

\begin{tabular}{|l|l|l|}
\hline Day & coblation & Conventional \\
\hline Minimum day & POD1 & POD 2 \\
\hline Maximum day & POD 3 & POD 3 \\
\hline
\end{tabular}

In coblation group return to normal diet was on POD1 which was earlier to POD 2 in conventional group.

Table 16:-Rate of complications

\begin{tabular}{|l|l|}
\hline Group & complications \\
\hline coblation & nil \\
\hline Conventional & Nil \\
\hline
\end{tabular}

In Both group patients developed nil complications

1. 50 patients were randomly divided in to two groups consisting of 25 each in coblation and conventional tonsillectomy group

2. Among the age group most of the patients belonged to 5-10 yrs in both groups. Minimum age was 5 yrs and maximum age was $19 \mathrm{yrs}$ in both groups.

3. Among sex distribution males were more when compared to females in both groups

4. Among symptoms most patients presented with odynophagia followed by throat discomfort in both groups and with combination of both associated with ear ache in few cases

5. Duration of symptoms ranged from 6months to 1 year in majority of patients in both groups

6. Grading of tonsil was grade 3 in most cases and grade 4 in few cases in both groups

7. Intra operative blood loss was compared. In coblation group minimal loss was $20 \mathrm{ml}$ and maximum was $70 \mathrm{ml}$ , in conventional group minimal loss was $55 \mathrm{ml}$ and maximum was $150 \mathrm{ml}$. Blood loss in coblation group was found to be minimal.

8. Post operativepain was assessed using visual analog scale.6 hrs post op in coblation group minimal score was 2 and maximum was 3,on POD-1,minimum was 1 and maximum was 2.

9. In conventional group $6 \mathrm{hrs}$ post op minimal score was 3 and maximum was 6 ,on POD-1, minimum was 1 and maximum was 3 .

10. Return to normal diet was compared in both groups.In coblation group minimum was day-1 and maximum was day-3.in conventional group minimum was day-2 and maximum was day-3.so return to normal diet was found earlier in coblation group.

11. Rate of complications were compared and were nil in both groups.

\section{Discussion:-}

1. Coblation tonsillectomy is recently introduced dissection method with few reports in the literature 
2. Coblation is a new method in soft tissue surgery.

3. It is used in the treatment of snoring,nasal congestion, and sleep apnoea has received much more interest

4. In ENT tonsillectomy is most commonly performed procedure and conventional method is considered as standard and most commonmethod

5. Tonsillectomy is also done by various other methods

6. In studies most of the newer techniques are compared with conventional method

7. The value of newer methods are compared based on intra operative and post operative morbidity and complications

8. The most common post operative complication following tonsillectomy is haemorrhage and pain

9. Post operative pain is the most common subjective symptom

10. In this study the time taken to control the bleeding influences on blood loss and blood loss was found to be decreased in coblation group

11. Post operative pain shoud be reduced because it impairs swallowing with risk of dehydration,infection and secondary haemorrhage.

12. Laser tonsillectomy and hot electrosurgery causes more post operative pain compared to conventional method

13. In this studypatients belonging to coblation group developed mild pain with minimal pain score of 1 and maximum of 3 seen at post operatively 6 hrs and on POD-1

14. In conventional group minimal pain score was 3 and maximum was 6 seen post operatively 6 hrs and on POD-1

15. In this study early return to normal diet was found in coblation group on day- 1 when compared to conventional group on day-2

16. There were no major complications noted in both groups.

\section{Conclusion:-}

1. This method was designed mainly to compare newer method coblation tonsillectomy with conventional tonsillectomy in aspects of amount of intra operative blood loss

2. Post operative pain

3. Early return to normal diet

4. Post operative complications

5. More significant results have been observed in all aspects with coblation method

6. This benefit suggests further evaluation and use of this method in future.

\section{Bibliography:-}

1. Lowe D, van der Meulen J, Cromwell D, Lewsey J, Copley L, Browne J, et al. Key messages from the National Prospective Tonsillectomy Audit. Laryngoscope. 2007;117(4):717-24. [PubMed]

2. Pinder DK, Wilson H, Hilton MP. Dissection versus diathermy for tonsillectomy. Cochrane Database Syst Rev. 2011;(3):CD002211. [PubMed]

3. Raut V, Bhat N, Kinsella J, Toner JG, Sinnathuray AR, Stevenson M. Bipolar scissors versus cold dissection tonsillectomy: a prospective, randomized, multi-unit study. Laryngoscope. 2001;111(12):2178-82. [PubMed]. 